\title{
Segmenting The Web 2.0 Market: Behavioural And Usage Patterns Of Social Web Consumers
}

\author{
Carlota Lorenzo-Romero, Ph.D., University of Castilla-La Mancha, Spain \\ Efthymios Constantinides, Ph.D., University of Twente, The Netherlands \\ María-del-Carmen Alarcón-del-Amo, Ph.D. Student, University of Castilla-La Mancha, Spain
}

\begin{abstract}
The evolution of the commercial Internet to the current phase, commonly called Web 2.0 (or Social Web) has firmly positioned the web not only as a commercial but also as a social communication platform: an online environment facilitating peer-to-peer interaction, socialization, co-operation and information exchange. Internet users are not any more passive consumers of information but are actively involved in online creation, editing, and dissemination of content. They form virtual communities and interact with each other making use of a variety of interactive applications like social-networking sites, online forums, blogs, and wikis. This new social environment entails new challenges and opportunities for marketers, practitioners and behavioural researchers encompassing an appealing and untapped research area. In this empirical study we develop a classification of Web 2.0 users. Segments are identified on the basis of socio-demographic features, involvement, usage of the Internet, online purchase behaviour, personality characteristics, and the degree of use of Social Web sites. We analyze the differences between user segments, their trust levels and satisfaction and conclude that the degree of online experience is one of the most important antecedents of trust and satisfaction with Web 2.0 applications. The study identifies issues of further research and ways that can help field marketers to better map and understand their online markets in order to utilize effectively the Internet and particularly of the Web 2.0 domain as part of their marketing strategy.
\end{abstract}

Keywords: Web 2.0, Social Web, Segmentation, Trust, Satisfaction, Internet Strategy

\section{INTRODUCTION AND OBJECTIVES}

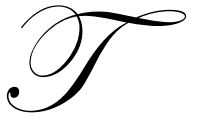

he emergence of Web 2.0 (or Social Web) has brought about a new virtual technological revolution; next to the typical capacities of the Web as sales channel and information instrument the Social Web presents users with new opportunities in the form of applications facilitating many innovative forms of interaction and communication. The most common and well-known Web 2.0 applications include the web logs (or blogs), chat sites, forums, online communities, file exchange sites and social networks. These applications are based on active user participation and provide consumers with emotional and practical benefits (Jaffray, 2007). As Riegner (2007) explains, user participation has far reaching commercial implications: consumers exercise great and increasing influence on product offerings and on the strategies used to sell them. All these possibilities have led to an increasing professional and academic interest in the study of the Social Web as part of the marketing strategy and as a new interaction environment between consumers and business ( $\mathrm{Li}, 2007 \mathrm{~b})$.

In this study, we are focusing on marketing aspects of this new virtual social context, with three main research objectives:

\footnotetext{
${ }^{1}$ This study has been funded through the Project with reference PL20101706 (Plan de Promoción de Investigación en el PDI, Vicerrectorado de Investigación, University of Castilla-La Mancha, Spain, 2010) and the Project with reference PCI08-0004 (Plan Nacional de Investigación Científica, Desarrollo e Innovación Tecnológica, JCCM, 2008-2010).
} 
- $\quad$ To establish a classification of Web 2.0 users (or 2.0 users), according to their patterns of participation in social applications. Most studies available are originating from commercial circles and limited academic research has been done regarding Web 2.0 users, their characteristics and their profiles.

- $\quad$ To define and describe the profiles of 2.0 users in a comprehensive way; this is done by combining a variety of parameters: socio-demographic aspects (gender and age), the frequency and duration of Internet access, access locations, online purchasing habits, participation in auctions (buying or selling), average expenditure in Internet purchases, Web 2.0 pages visited (differentiating blogs, social tools, file-sharing sites and other Web 2.0 applications) and the individual's character in terms of level of extroversion.

- Finally, as two important foundations of the social web are trust and mutual confidence, we analyze the differences between the different types of 2.0 users on the basis of trust in the Internet and the level of satisfaction with it.

With the above objectives in mind a survey was conducted intended to identify profiles of Internet users based on their usage patterns and also allow us to analyze the relation between users' trust and satisfaction with the Internet and their predisposition to use Web 2.0 tools.

The study includes a literature review presenting the main research findings about Web 2.0, specifically focused on principles, foundations, philosophy the profiles of the 2.0 users. The third section covers the methodology followed in designing and carrying out this research. The last section presents the main results obtained, the main conclusions and the future research issues. The segmentation methodology followed for segmenting Web 2.0 markets in this study is much more extensive and comprehensive than previous ones. In this sense the proposed taxonomy presents academics with new insights in the complex behaviour of the Social Web public and practitioners with useful knowledge for integrating this domain into their marketing strategy.

\section{CONCEPTUAL BACKGROUND}

\section{Web 2.0: Scope and basic concepts}

It is difficult to get a uniform definition or find consensus about what the term Web 2.0 means in the literature; this because it is a relatively new term encompassing a variety of online applications and services based on a common philosophy and principles. O'Reilly (2005) defines Web 2.0 as a range of services such as blogs, wikis, folksonomies and social-networking, based on communities of users who exchange information often and easily. Anderson (2007) groups these services together and explains that they help to create a more social Web in which everyone is able to add and alter content. Constantinides and Fountain (2008) isolate the three elements of the Web 2.0 (Applications, Social Effects and Enabling Technologies) and define it as a collection of online, interactive, open-source applications allowing the exchange of knowledge and user experiences; users accumulate knowledge and market power increasing their influence on social processes and businesses. According to the same authors the Web 2.0 allows the creation of informal networks facilitating the flow of ideas and knowledge in the form of customer-generated new content. Ribes (2007) defines the Web 2.0 as the Internet tools and services based on databases and in which Internet users can create and edit content. Cobo and Pardo (2007) propose a taxonomy of Web 2.0 applications and tools identifying four main application categories: Social Networking (i.e. Tools and applications for designing and creating websites to facilitate and promote social interchange spaces and communities); User Generated Content (Applications that allow users to generate information in virtual environments using tools for upload and download contents and for writing, disseminating and bartering information); Intelligent Information Organization (Tools, applications and resources that facilitate the arrangement, labelling, organization and arrangement of the information); and Mushups (Applications that allow the combination of resources and applications from different websites to offer an added value service).

The difference between traditional web sites and Web 2.0 sites lies in the fact that in the former individuals or organizations can merely present information about themselves and their activities in an one-way, downwards communication pattern (Arroyo, 2007) while in the interactive Web 2.0 the communication becomes two-way: downwards and upwards. O'Reilly (2005) states that network effects are obvious in this environment since a true Web 2.0 application becomes more valuable the more people use it. The key is the size of the users group and the search for balance between personal interests and public assets. Rheingold (2002) suggests that technology 
convergence has profound social repercussions; this because people use tools allowing them to adopt new forms of interaction, coordination and cooperation. These new forms facilitate the exchange of collective knowledge and the accumulation of a social capital, generated when social networking, trust, reciprocity, standards and values are shared encouraging people to collaborate and cooperate (Rheingold, 2005). O'Reilly (2005) defines this as the "architecture of participation" which underlines the need for Web 2.0 web sites allowing user participation, so that the architecture of participation is built around individuals, not around the technology.

\section{The Web 2.0 user profiles}

The Internet user profile has changed considerably with the emergence of Web 2.0. During the 90s the average online customer used the Internet as a mere tool to help solve day-to-day problems requiring information; with the emergence of Web 2.0, users are increasingly participants in content creation. Ortega (2007) refers to a "2.0 generation", " 2.0 profile", "2.0 attitude" or even a " 2.0 personality". The user's attitude is what distinguishes a 2.0 user from an Internet user. In this sense, this author defines four kinds of user interaction: passive, participative, cooperative and collaborative. According to the author the Web 2.0 users provide content, share it with peers and collaborate online. Web 2.0 sites become spaces of sociability where discussion, opinion sharing and mutual collaboration are encouraged. The social approval arising from this mutual collaboration feeds the egocentric temptation which Rheingold (2002), Rosen (2005), and Rizzolatti and Sinigaglia (2006) call "egoboost", "egocasting" or "mirror neurons", a feeling of satisfaction the 2.0 user obtains from participation and collaboration with others.

Riegner (2007) defines five segments of Web 2.0 users according to the volume of web content they create and the volume of their online purchases, calling them "Online Insiders", "Social Clickers", "Content Kings", "Everyday Pros" and "Fast Trackers". "Online Insiders" are very active in the edition of web contents, interested in finding new products, passing on their experiences and in general make online purchases frequently. "Social Clickers" are young consumers, making online communications habitually, as much as the previous group, but are more reticent about making online purchases. The third segment, the "Content Kings," are young Internet users with great experience in peer-to-peer (P2P) file transfer, posting comments on forums and chat sites and having personal web sites. "Everyday Pros" habitually make online purchases, even to the extent of having an influence on product design, but do not participate in blogs or personal web sites. Finally, "Fast Trackers" are those who spend more time in receiving information and communicating than in creating or editing content; these could be considered as rather passive users.

From the practitioners quarters Forrester Research has developed a segmentation methodology called Social Technographics. The method is based on identification of social media use and attitude patterns. According to the use and attitudes to social media tools, they propose a segmentation of six levels of participation in social technologies. The Forrester taxonomy ranges between two extreme positions. On one side, the "creators" represent active participants who publish blogs, create and maintain websites and upload content. They are predominantly young - teenagers create more than other group - and there is not any gender difference. Lower in the ladder we find three other groups called "critics", "collectors" and "joiners". They participate by incorporating content expressing their interactive behaviour by using different tools. On the lower levels of the ladder the "spectators" can be considered as passive users, and the "inactives" do not participate at all in social web applications. These last two groups tend to be older, mainly female and not self perceived as natural leaders (Li, 2007a). Although the nature and size of the different groups probably will be different across cultures and countries, the idea of classifying consumers according their use of social media is an appealing one. This continuum from active to passive regardless of the tag used to label the group seems to be a prevailing approach across this incipient research domain.

\section{Trust and satisfaction with the Internet}

The basic principles underpinning the Web 2.0 are related to the ideas of sharing, continuous improvement, the role of the user as the main source of information and the harnessing of collective intelligence; these principles combined with trust have led to the emergence of a 2.0 attitude while technology is becoming of secondary importance. The attitude of users has changed; from mere consumers of information, they have become content generators. This change is due to the development of the principles enhancing trust and taking advantage of the 
collective intelligence. Ample trust in fellow users means trusting their opinions and information they provide online and trusting the way they use Web 2.0 services. It is the idea underlying many projects such as the Wikipedia. If there is no trust, existence of spaces based on user participation does not make sense (Margaix, 2007).

Trust has been considered a key factor in the success of relationships between companies in the context of industrial marketing (Hakansson, 1982) and together with commitment and satisfaction is one of the basic foundations on which relationship marketing is based (Delgado and Munuera, 2002). Trust is considered as a factor favouring the continuity of a relationship (e.g. Anderson and Barton, 1989; Anderson and Narus, 1990; Berry, 1995; Bigné and Blesa, 2003; Dwyer et al., 1987; Morgan and Hunt, 1994) which is why the individual's trust is a key factor in the adoption of Internet as a sales channel (Hoffman et al., 1999). In fact, the low rates of conversion from Internet users to buyers (Culnan and Armstrong, 1999) seem to be related with the low levels of trust existing (Korgaonkar and Wolin, 1999; Jarvenpaa et al., 2000; Luo, 2002). Some researchers underline that greater familiarity with use of web sites increases the trust in it (Gefen, 2000; Walczuch et al., 2001) decreasing fear of technology and moderating effects related to the consumer's personality background.

Next to trust, satisfaction is essential for the maintenance of online relationships. The notion of satisfaction involves both fulfilment of expectations placed in a web site and a positive emotional state based on the results obtained from maintenance of the relationship with that site (Ganesan, 1994).

\section{METHODOLOGY}

The literature suggests that the more someone is involved and familiar with Web 2.0 interactive tools and applications the more he will trust and will be satisfied with the virtual medium. Starting from this general premise, the intention of this study is to develop a classification of user types according to their level of participation in Web 2.0 tools and visits to Web 2.0 pages, define the profiles according to socio-demographic characteristics and personality, and then determine any differences between segments in trust in and satisfaction with Internet.

The method followed was to carry out a survey of Internet users that are familiar with the Internet environment. The survey was carried out in May 2008. The final sample is composed by 386 Spanish Internet users. In order to that various subgroups of the target population are proportionally represented in the sample, a nonprobability method by quota sampling was used.

The questionnaire included questions about the use of Web 2.0 tools and applications (both general and specific applications) and questions about more general behavioural dimensions such as use rates or online shopping behaviour patterns. Finally, scales to measure satisfaction and trust with the Internet were also developed.

\section{RESULTS}

The analytical process followed in our research consisted of a number of stages. First, in order to determine the types of Web 2.0 users, we carried out a conglomerate analysis using as criterion the level of participation in Web 2.0 tools. In this stage we also analyzed the existence of significant differences between the clusters with regard to profile of socio-demographic characteristics, use of the web and online purchase habits, personality and visits to Web 2.0 sites, in order to define the profile of 2.0 users. This stage was meant to achieve the objectives 1 and 2 identified earlier. In order to achieve the third and final objective, we carried out an analysis of the validity

and reliability of the scales used to measure the user's trust level and satisfaction with the Internet. The purpose of this analysis was to identify any significant differences between the clusters obtained and their levels of trust and satisfaction.

\section{Typology of Web 2.0 users}

The cluster analysis was intended to group the different individuals of our sample into groups according to their level of participation in the different Web 2.0 tools. This analysis identified three, well differentiated segments which we have identified as "embryonic," "amateur" and "expert" 2.0 users. 
- The "embryonic" 2.0 user limits his / her social online activity to file sending and file creation. They are usually female, age over 40, with a very low frequency of access (a few times a month) and do not make any online purchase of products or services.

- The "amateur" 2.0 user is characterized by participation in online forums and the frequent posting of opinions, comments, products reviews etc. "Amateurs" tend to be female, between 26 and 39, with an Internet access frequency of several times a week from home and daily from work. They usually spend between 10 and 30 hours a week in Internet. During the last year, they made fewer than 10 online purchases of products or services spending between 300 and 600 Euros; they have also sold something through an auction site during the last year.

- The "expert" 2.0 user has the most interactive online profile, sending messages over distribution lists, adding content to wikis, posting in his blogs or commenting in other blogs and also designing/customizing products or services according to his interests and taste. "Experts" are usually male, under 25, with a frequency of Internet access from home of several times a day. The average time spent browsing the Internet is over 30 hours a week. They are also characterized by having made more than 10 online purchases during the last year with an average annual expenditure on online purchases higher than 600 Euros. They also frequently buy and sell products through auction sites.

Comparison of the "expert" and "amateur" 2.0 user groups with the "embryonic," reveals significant differences - to a significance level of 5\% - to the numbers of Web 2.0 sites visited. Differences of a lower significance level - specifically $10 \%$ - were also found between "expert" and "amateur" users; the higher the number of Web 2.0 site visits made the higher the Internet experience. Grouping the Web 2.0 sites visited into blogs, social tools (social networking sites, markers, mobile and access communities, content recommendations, news, wikis, etc.), sites for file sharing (podcasts, sharing photos or videos, etc.) and other Web 2.0 applications (online applications, map-based applications, customized start pages, specialized 2.0 search engines, aggregators, RSS readers, etc.), we see that there are significant differences in the number of pages visited by "expert" 2.0 and "embryonic" users. However, if we compare them with "amateur" users, these differences are only significant in the case of file sharing and applications included in the category "other Web 2.0 applications". In addition, comparison of "amateur" and "embryonic" users shows that there are differences in the kind of Web 2.0 sites which include other applications.

Finally, using the personality scale of Goldberg (1992) to determine the individual's extroversionintroversion level, significant differences were found in the personality of "expert" and "embryonic" Web 2.0 users, the former being much more extrovert than the latter.

\section{Trust and satisfaction of the Web 2.0 users}

In this section, we examine whether there are differences in the levels of trust and satisfaction between the different types of Web 2.0 users. For this purpose, first we look at the validity and reliability of the trust and satisfaction scales and then carry out a variance analysis to determine whether significant differences exist between the different user groups.

\section{Validity and reliability analysis of the trust and satisfaction scales}

The validity of a scale means that the measurement instrument used quantifies the factor we want to measure and not other factors. In this case we consider the three classic dimensions of validity: content validity, convergent validity and discriminant validity.

The content validity of the scale is a result of suitable, preliminary review of the literature. To ensure this type of validity, an in-depth review of the different scales proposed for the constructs was carried out (Table 1). 
Table 1. Content validity

\begin{tabular}{|c|l|}
\hline Construct & \multicolumn{1}{c|}{ Sources } \\
\hline \multirow{2}{*}{ Trust } & $\begin{array}{l}\text { Ganesan (1994); Kumar } \text { et al. (1995); Doney and Cannon (1997); Siguaw et al., (1998); Roy et al. (2001); } \\
\text { Harris and Goode (2004); Flavián and Guinalíu (2007). }\end{array}$ \\
\hline \multirow{3}{*}{ Satisfaction } & $\begin{array}{l}\text { Oliver (1980); Oliver and Linda (1981); Churchill and Surprenant (1982); Bearden and Teel (1983); Oliver and } \\
\text { Bearden (1983); Yi (1990); Oliver (1997); Smith and Barclay (1997); Bhattacherjee (2001); Severt (2002); } \\
\text { Janda } \text { et al. (2002), Montoya-Weiss } \text { et al. (2003); Anderson and Srinivasan (2003); Harris and Goode (2004); } \\
\text { Bennett } \text { et al. (2005). }\end{array}$ \\
\hline
\end{tabular}

Different confirmation analyses were then carried out in order to refine the trust and satisfaction scales, and assess their validity and reliability levels. Definitive refinement was based on the methodology of "Development of Structural Models" (Hair et al., 2006). This technique consists of eliminating items which do not match any of the three criteria proposed by Jöreskog and Sörbom (1993): The weak convergence criterion (Steenkamp and Van Trijp, 1991) means removing indicators which do not have significant factorial regression coefficients; the strong convergence criterion (Steenkamp and Van Trijp, 1991) means removing insubstantial indicators, i.e., those with standardized coefficients of less than 0.5 (Hildebrant, 1987); finally, Jöreskog and Sörbom (1993) propose removal of indicators which contribute least to explanation of the model.

The above mentioned content validity analysis allowed us to make an initial proposal of scales. Specifically, the scale used to measure trust was made up of 15 items and the satisfaction scale of 7 items. However, performance of the refinement analysis described gave us a model with a trust scale consisting of three variables and a satisfaction scale consisting of four measurements on a five-point Likert scale (Table 2).

Table 2. Scales used to measure trust and satisfaction

\begin{tabular}{|c|c|l|}
\hline Construct & \multicolumn{2}{|c|}{ Items used } \\
\hline \multirow{3}{*}{ Trust } & V1 & I believe web sites usually fulfil the promises they make \\
\cline { 2 - 3 } & V2 & I believe the information offered on web sites is sincere and honest \\
\cline { 2 - 3 } & V3 & Web sites are characterized by their openness and transparency in offering their services to users \\
\cline { 2 - 3 } & V4 & I believe I can trust in most web sites \\
\hline \multirow{3}{*}{ Satisfaction } & V5 & Internet meets my expectations \\
\cline { 2 - 3 } & V6 & The experience of using Internet is satisfactory \\
\cline { 2 - 3 } & V7 & I am satisfied with the products/services that the Internet offers \\
\hline
\end{tabular}

To compare the convergent validity of the proposed scales, the items must be significant and strongly correlated with the latent variables they are measuring. Hair et al. (2006) recommend that all factor loadings should be significant and the average of the item-to-factor loadings should be higher than 0.7. As seen in Table 3 all parameters of both scales are significant and the mean variable load is greater than 0.7 , therefore they have convergent validity.

Table 3. Reliability and convergent validity

\begin{tabular}{|c|c|c|c|c|c|c|}
\hline Factor & Indicator & Loading & $\mathbf{t}$ & Cronbac's $\alpha$ & CRI & AVE \\
\hline \multirow{4}{*}{ F1 (trust) } & V1 & 0.615 & 9.278 & \multirow{4}{*}{0.754} & \multirow{4}{*}{0.769} & \multirow{4}{*}{0.46} \\
\hline & V2 & 0.803 & 12.593 & & & \\
\hline & V3 & 0.663 & 10.136 & & & \\
\hline & V4 & 0.605 & 9.103 & & & \\
\hline \multirow{3}{*}{ F2 (satisfaction) } & V5 & 0.833 & 13.256 & \multirow{3}{*}{0.814} & \multirow{3}{*}{0.799} & \multirow{3}{*}{0.57} \\
\hline & V6 & 0.754 & 11.904 & & & \\
\hline & V7 & 0.672 & 10.515 & & & \\
\hline
\end{tabular}

To test the discriminant validity of the scales, we used two procedures, the confidence interval test and the extracted variance test. Table 4 shows how the scales have discriminant validity. First, none of the 95 per cent confidence intervals of the individual elements of the latent factor correlation matrix contained a value of 1.0 
(Anderson and Gerbing, 1988). Second, the shared variance between pairs of constructs was always less than the corresponding Average Variance Extracted (AVE; Fornell and Larcker, 1981).

Table 4. Discriminant validity between constructs

\begin{tabular}{|c|c|c|}
\hline & F1 & F2 \\
\hline F1 & 0.46 & $\begin{array}{c}{[\mathbf{0 . 1 6}, \mathbf{0 . 4 6}]} \\
\text { (confidence interval for factor correlation) }\end{array}$ \\
\hline $\mathbf{F 2}$ & $\begin{array}{c}0.09 \\
\text { (factor correlation) }\end{array}$ & 0.57 \\
\hline
\end{tabular}

Reliability of the constructs is presented in Table 3 and demonstrates high-internal consistency of the constructs. In each case, Cronbach's alpha and the composite reliability index (CRI) exceeded Nunnally and Bernstein's (1994) recommendation of 0.70. AVE was also calculated for each construct, resulting for which values equal to or greater than 0.5 are recommended (Forner and Larcker, 1981); this minimum is usually very conservative and the literature is full of examples of accepted scales with lower AVEs. The AVE requirement is met for the satisfaction scale while the trust scale nearly meets it - given that, as we have said, scales with AVE below 0.5 are usually accepted it. This finding provides evidence supporting the reliability of the indicators.

On the basis of the above criteria that scales used in the study which measure the individual's trust and satisfaction with the Internet provide sufficient evidence of reliability, convergent and discriminant validity. In addition the model's fit is good as it complies with all requirements i.e., it does not have a significant $\chi^{2}$, so the null hypothesis that the estimated variance matrix coincides with the sample is rejected; the SRMR (Standardized RMR) also indicates that the model's fit is good, its value being below 0.05, and the CFI (Comparative Fit Index) and NNFI (Non normed fit index) are over 0.9.

\section{Differences in trust and satisfaction between different Web 2.0 users' profiles}

To find out whether there are significant differences between the different groups with regard to the trust they said they had in Internet, we performed an Analysis of the Variance (ANOVA) (Tables 3 and 4).

With regard to trust (Table 5), Tukey's Honestly Significant Differences test (HSD) shows that there are no differences significant at $5 \%$ between the averages of the different types of 2.0 user for any item on the scale. However, for the item "web sites are characterized by their openness and transparency in offering services to users," the average difference between the answers of "amateur" and "expert" users is significant to 10\%, "expert" users having more trust than "amateur" ones.

Table 5. Multiple Comparison Test for Trust (Tukey's HSD).

\begin{tabular}{|c|c|c|c|c|}
\hline Scale Item & $\begin{array}{l}\text { Web 2.0 User } \\
\text { (I) }\end{array}$ & $\begin{array}{l}\text { Web 2.0 User } \\
(\text { (J) }\end{array}$ & $\begin{array}{c}\text { Means } \\
\text { differences } \\
\text { (I-J) }\end{array}$ & Sig. \\
\hline \multirow{3}{*}{ I believe web sites usually fulfil the promises they make } & Expert & Embryonic & 0.027 & 0.968 \\
\hline & Expert & Amateur & 0.114 & 0.614 \\
\hline & Embryonic & Amateur & 0.087 & 0.713 \\
\hline \multirow{3}{*}{$\begin{array}{l}\text { I believe the information offered on web sites is sincere and } \\
\text { honest }\end{array}$} & Expert & Embryonic & 0.123 & 0.548 \\
\hline & Expert & Amateur & 0.134 & 0.533 \\
\hline & Embryonic & Amateur & 0.011 & 0.995 \\
\hline \multirow{3}{*}{$\begin{array}{l}\text { Web sites are characterized by their openness and transparency } \\
\text { in offering their services to users }\end{array}$} & Expert & Embryonic & 0.083 & 0.747 \\
\hline & Expert & Amateur & $0.263 * *$ & 0.082 \\
\hline & Embryonic & Amateur & 0.180 & 0.241 \\
\hline \multirow{3}{*}{ I believe I can trust in most web sites } & Expert & Embryonic & 0.177 & 0.401 \\
\hline & Expert & Amateur & 0.139 & 0.609 \\
\hline & Embryonic & Amateur & -0.038 & 0.957 \\
\hline
\end{tabular}


With regard to the satisfaction of the different user groups, for the variable "the experience of using Internet is satisfactory" there is a difference with a significance of more than $5 \%$ between "amateur" and "embryonic" 2.0 users, the higher degree of satisfaction being that of "amateur" users (Table 6).

Table 6. Multiple Comparison Test for Satisfaction (Tukey's HSD)

\begin{tabular}{|c|c|c|c|c|}
\hline Scale Item & $\begin{array}{l}\text { Web 2.0 User } \\
\text { (I) }\end{array}$ & $\begin{array}{l}\text { Web 2.0 User } \\
(\text { (J) }\end{array}$ & $\begin{array}{c}\text { Means } \\
\text { differences } \\
\text { (I-J) }\end{array}$ & Sig. \\
\hline \multirow{3}{*}{ Internet meets my expectations } & Expert & Embryonic & -0.020 & 0.980 \\
\hline & Expert & Amateur & -0.221 & 0.109 \\
\hline & Embryonic & Amateur & -0.201 & 0.113 \\
\hline \multirow{3}{*}{ The experience of using Internet is satisfactory } & Expert & Embryonic & 0.073 & 0.748 \\
\hline & Expert & Amateur & -0.203 & 0.142 \\
\hline & Embryonic & Amateur & $-0.276^{*}$ & 0.014 \\
\hline \multirow{3}{*}{$\begin{array}{l}\text { I am satisfied with the products/services that the Internet } \\
\text { offers }\end{array}$} & Expert & Embryonic & 0.090 & 0.661 \\
\hline & Expert & Amateur & -0.111 & 0.576 \\
\hline & Embryonic & Amateur & -0.201 & 0.119 \\
\hline
\end{tabular}

The results obtained from the study confirmed that findings referring to the earlier Internet environment (Web 1.0) still apply in the new Web 2.0 environment. Earlier studies conclude that greater familiarity with the use of web sites results in higher confidence in them (Gefen, 2000; Walczuch et al., 2001); the level of use of the Net determines how easily or how difficult a consumer can establish and maintain a relationship of trust with a web site. The lacks of physical contact and malicious actions (hacking, scams, and viruses) are elements reducing trust (Constantinides, 2004). These actions avert people with low levels of experience and trust in engaging in online activity. For all these reasons, customary use of web sites should be encouraged to increase awareness and skills of people in their use. In addition, satisfaction with the Internet is essential to build up long term relationships online. Satisfaction requires meeting the expectations people have when using a web site and a positive emotional state based on the results obtained from maintenance of the relationship with that site (Ganesan, 1994). For all these reasons, it is not surprising that "expert" Web 2.0 users have greater trust than "amateurs" and that the later are in turn more satisfied with the online medium than the "embryonic" Web 2.0 users.

\section{CONCLUSIONS, LIMITATIONS AND FUTURE RESEARCH LINES}

Web 2.0 can be defined as "all Internet services and tools which are based on a database which Internet users can modify, whether in terms of content (adding, deleting or editing information or relating information with existing information), its presentation, or both" (Ribes, 2007). The Web 2.0 environment has become a platform of personal communication, networking and interaction with numerous user communities and a wide range of services, such as social networking sites, blogs, online forums, wikis and folksonomies. These applications offer online users an easy access and direct participation in the virtual environment.

Internet users may use 2.0 tools with various degrees of intensity depending on how such tools are used. A 2.0 user can simply visit Web 2.0 sites but can also contribute, disseminate, share and collaborate (Ortega, 2007).

In this study, we have developed a typology of Web 2.0 users based on the differences between them in terms of usage, trust and satisfaction with the Web 2.0 environment. The three segments of Web 2.0 users obtained were classified into "embryonic," "amateur" and "expert".

"Embryonic" Web 2.0 users are characterized by exclusively using the Internet for file sending/creation, being usually female, aged over 40 . The frequency of Internet use is much lower than the other two user segments while "Embryonic" users do not make online purchases. "Amateur" Web 2.0 users are not passive users; they take part in forums, post opinions, comments, and products reviews online. The majority is female, between 26 and 39, with an Internet access frequency greater than that of "embryonic" users. They sporadically make online purchases and make use of auction sites. 
"Expert" Web 2.0 users have the most interactive profile from all segments. Their activities include publishing blogs and posting comments in other blogs, sending messages over distribution lists, adding content to wikis, designing or customizing products / services according to their needs and interests. The majority is male, under 25 years old, with a frequency of Internet access from home greater than that of the other user types: they are several times a day or even the whole day online. They make often online purchases spending more than 600 Euro per year and often they buy and sell through auction sites.

A general conclusion of the study is that the degree of experience with the Internet is directly related to the number of visits to Web 2.0 sites made. In addition, we have verified that there are significant differences in the personalities of each user type, the "expert" users being characterized by a higher level of extroversion than the "embryonic" users.

The results obtained by the study with regard to the levels of trust and satisfaction of the different Web 2.0 users are in line with findings of earlier studies, showing that greater familiarity with Web is accompanied by higher trust in and satisfaction with Internet, "expert" users having more trust and satisfaction than "amateur" ones and "amateur" users being more satisfied and trust to Internet applications than "embryonic" users.

Regarding the practical implications of the study there are quite a few to mention. Field marketers considering including Web 2.0 applications in their (online) communication mix must be first of all aware of the maturity of their potential customers as to the use of the Internet and particular their attitudes towards Web 2.0 applications.

Segmenting their market across the lines of the proposed segmentation presents marketers with a good picture of the segment profiles and gives them useful information in order to estimate their size and market potential in terms of online purchasing. Plotting the segment profiles, potential with the company's target market provides practitioners with a sound basis for deciding whether certain Web 2.0 strategies are potentially effective or not. For example a producer of products targeting female customers would be not very successful in involving his target group in Web 2.0 induced interaction (for example engaging customers in product reviews or co-creation) since customers who participate in such activities are mainly males. Similarly if a producer's target market includes mainly "Embryonic" types as customers then most probably there is little to learn about customer experiences, complains or product problems by following the customer voice in blogs or online forums; these segment is not active in providing content in such Web 2.0 sites.

The second practical implication is the conclusion that online marketers should be aware of the need to provide an online experience of high quality as a way to help customers to build trust for their brand or product but most importantly help customers in building trust and satisfaction towards the company's Internet presence. The more people trust and the more satisfied they are when interacting or transacting with "traditional" Web 1.0 types of web sites the more the likelihood that they will increase their use of Web 2.0 applications and become more mature Internet users. Such a development would increase the options of online marketers in improving communication and contacts with their target groups by engaging Social Media as part of their communication toolbox. The more the Web 2.0 based media become mainstream (and all indications are that they are about to reach this stage) the more important role they will be able to play as part of the marketing strategy.

The main limitation of the study is the fact that it was conducted among residents of one country and therefore one should be cautious with the generalization of the findings. Cross-cultural studies with similar methodologies in other countries could provide a more complete picture of the European. Another direction regarding future research work in the domain of online trust and satisfaction should be the inclusion of other user intrinsic constructs such as the perceived risk, perceived benefits and ease of use in order to examine their effect on the use of Web 2.0 applications. Such research will contribute to the development and empirical analysis of a causal model which provides a more accurate vision of the influence relationships between the variables under study and a better picture of the customer behaviour in Web 2.0 mediated environments. 


\section{AUTHOR INFORMATION}

Carlota Lorenzo-Romero: Degree in Business Administration and $\mathrm{PhD}$ on E-Marketing from University of Castilla-La Mancha (Spain). Currently Assistant Professor in Marketing at Business Administration Department. Faculty of Economics and Business of Albacete, University of Castilla-La Mancha (Spain). Research Interest: Electronic commerce, Web 2.0, Social Networking Sites, store atmosphere, e-merchandising, consumer behaviour, marketing research, experimental designs, and quantitative analysis. E-mail: Carlota.Lorenzo@uclm.es

Efthymios Constantinides: Degree in Economics in Athens and followed post graduate studies in Economics of European Integration in Amsterdam. He received his $\mathrm{PhD}$ on Marketing in Virtual Environments. After a corporate career of ten years he worked for 10 years as senior lecturer Marketing for the International Agricultural College Larenstein, (The Netherlands) and since 2001 works as Assistant Professor E-Commerce at the school of Management and Governance of the University of Twente (The Netherlands). Research Interest: consumer behaviour and marketing strategy in virtual environments; in particular on utilizing the Social Web environment as source of market intelligence and as active marketing instrument. E-mail: e.constantinides@utwente.nl

María-del-Carmen Alarcón-del-Amo: Degree in Business Administration at the University of Castilla-La Mancha (Spain). Currently $\mathrm{PhD}$ student on Marketing at the same University. She has received a $\mathrm{PhD}$ grant for four years to develop her Thesis. Research Interest: Web 2.0, Social Networking Sites, consumer behaviour, marketing research, and quantitative analysis. E-mail: MCarmen.Alarcon@uclm.es

\section{REFERENCES}

1. Anderson, P. (2007): "What is Web 2.0? Ideas, technologies and implications for education". JISC Technology and Standards Watch. February. Available at: http://www.educause.edu/ir/library/pdf/ERM0621.pdf

2. $\quad$ Anderson, E. and Barton, W. (1989): "The Use of Pledges to Build and Sustain Commitment in Distribution Channels". Journal of Marketing Research, 29 (February), 18-34.

3. Anderson, E. and Gerbing, D.W. (1988): "Structural equation modelling in practice: A review and recommended two-step approach". Psychological Bulletin, 103, 411-423.

4. Anderson, J.C. and Narus, J.A. (1990): "A Model of Distribution Firm and Manufacturer Firm Working Partnerships". Journal of Marketing, 54 (January), 42-58.

5. Anderson, R.E. and Srinivasan, S.S. (2003): "E-satisfaction and e-loyalty: A contingency framework". Psychology \& Marketing, 20 (2), 123-138.

6. Arroyo, N. (2007): “¿Web 2.0? ¿web social? ¿qué es eso?” [“Web 2.0?, Social Web? What it is?”]. Educación y biblioteca, 161, 69-74. [Spanish]

7. Bearden, W.O. and Teel, J.E. (1983): "Selected determinants of customer satisfaction and complaint reports". Journal of Marketing Research, 20 (1), 21-28.

8. Bennett, R., Hartel, C.R. and McCollkennedy, J.R. (2005): "Experience as a moderator of involvement and satisfaction on brand loyalty in a business-to-business setting". Industrial Marketing Management, 34, 97107.

9. Berry, L.L. (1995): "Relationship Marketing of Services - Growing Interest, Emerging Perspectives". Journal of the Academy of Marketing Science, 23 (4), 236-245.

10. Bhattacherjee, A. (2001): "An empirical analysis of the antecedents of electronic commerce service continuance". Decision Support Systems, 32 (2), 201-214.

11. Bigné, E. and Blesa, A. (2003): "Market Orientation, Trust and Satisfaction in Dyadic Relationships: A Manufacturer-Retailer Analysis". International Journal of Retail \& Distribution Management, 31 (11), 574-590.

12. Churchill, G.A.JR. and Surprenant, C. (1982): “An investigation into the determinants of customer satisfaction". Journal of Marketing Research, 19 (4), 491-504.

13. Cobo, C. and Pardo, H. (2007): Planeta web 2.0. Inteligencia colectiva o medios fast food [Web 2.0 planet. Collective intelligence or fast food media]. Barcelona / México DF: Grup de Recerca d'Interaccions Digitals, , Universitat de Vic. Flacso México. [Spanish] 
14. Constantinides, E. (2004): "Influencing the online consumer's behaviour: The web experience". Journal of Internet Research, 14 (2), 111-126.

15. Constantinides, E. and Fountain, S.J. (2008): "Web 2.0: Conceptual foundations and marketing issues". Journal of Direct, Data and Digital Marketing Practice, 9 (3), 231-244.

16. Cronbach, L. (1951). "Coefficient alpha and internal structure of test". Psychometrika, 16, $297-334$.

17. Culnan, M.J. and Armstrong, P.K. (1999): "Information Privacy Concerns, Procedural Fairness, and Impersonal Trust: An Empirical Investigation”. Organization Science, 10 (1), 104-116.

18. Delgado, E. and Munuera, J.L. (2002): "Brand Trust in the Context of Consumer Royalty". European Journal of Marketing, 75, 16-20.

19. Doney, P.M. and Cannon, J.P. (1997): “An Examination of the Nature of Trust in the Buyer-Seller Relationship". Journal of Marketing, 51 (April), 35-51.

20. Dwyer, F.R., Schurr, P.H. and Oh, S. (1987): "Developing Buying-Seller Relationships". Journal of Marketing, 52, 11-27.

21. Flavián, C. and Guinalíu, M. (2007): "Un análisis de la influencia de la confianza y del riesgo percibido sobre la lealtad a un sitio web: el caso de la distribución de servicios gratuitos" ["An analysis of trust and perceived risk influence on website loyalty: The case of the free services distribution"]. Revista Europea de Dirección y Economía de la Empresa, 16 (1), 159-178. [Spanish]

22. Fornell, C. and Larcker, D. (1981): "Structural equation models with unobservable variables and measurement error". Journal of Marketing Research, 18 (1), 39-50.

23. Ganesan, S. (1994): "Determinants of long-term orientation in buyer-seller relationships". Journal of Marketing, 58, 1-19.

24. Gefen, D. (2000):'E-commerce. The role of familiarity and trust'. The International Journal of Management Science, 28, 725-737.

25. Goldberg, A.L. (1992): "The mechanism and functions of ATP-dependent proteases in bacterial and animal cells". European Journal of Biochemistry, 203 (1-2), 9-23.

26. Hair, J.F., Anderson, R.E., Tatham, R.L. and Black, W.C. (2006). Multivariate Data Analysis. 6th ed. New York: Prentice Hall.

27. Hakansson, H. (1982): "Relationship and competitive Streght”. In: H. Hakansson, ed. International Marketing and Purchasing of Industrial Goods. Chichester: John Wiley and Sons, 381-394.

28. Harris, L.C. and Goode, M.M.H. (2004): "The four levels of loyalty and the pivotal role of trust: a study of on-line service dynamics". Journal of Retailing, 80, 139-158.

29. Hildebrant, L. (1987): "Consumer Retail Satisfaction in Rural Areas: A Reanalysis of Survey Data”. Journal of Economic Psychology, 8, 19-42.

30. Hoffman, D.L., Novak, T.P. and Peralta, M. (1999): "Building consumer trust on-line". Communications of the ACM, 42, 80-86.

31. Jaffray, P. (2007): The User Revolution: The New Advertising Ecosystem and the Rise of the Internet as a Mass Medium [online]. Available at: http://www.piperjaffray.com [Accesed 8 January 2008].

32. Janda, S. Trocchia, P. and Gwinner, K. (2002): "Consumer perceptions of Internet retail service quality". International Journal of Service Industry Management, 13, 421-431.

33. Jarvenpaa, S.L., Tractinsky, N. and Vitale, M. (2000): “Consumer Trust in an Internet Store”. Information Technology and Management, 1 (1-2), 45-71.

34. Jöreskog, K.G. and Sörbom, D. (1993): LISREL 8: Structural Equation Modeling with the SIMPLIS Command Language. Chicago, IL: Ed. Scientific Software International.

35. Korgaonkar, P.K. and Wolin, L.D. (1999): “A Multivariate Analysis of Web Usage”. Journal of Advertising Research, (March-April), 53-68.

36. Kumar, N., Scheer, L.K. and Sreenkamp, J.B. (1995). "The Effects of Supplier Fairness on Vulnerable Resellers". Journal of Marketing Research, 32 (1), 42-53.

37. Li, C. (2007a): Social Technographics ${ }^{\circledR}$ Mapping Participation In Activities Forms The Foundation Of A Social Strategy [online]. Forrester Research Document. Available at: http://www.forrester.com/Research/Document/Excerpt/0,7211,42057,00.html [Accessed 12 January 2008 ].

38. Li, C. (2007b): How Consumers Use Social Networks [online]. Forrester Research Document. Available at: http://www.forrester.com/Research/PDF/0,5110,41626,00.pdf [Accessed 12 January 2008].

39. Luo, X. (2002): "Trust Production and privacy Concerns on the Internet. A Framework Based on Relationship Marketing and Social Exchange Theory”. Industrial Marketing Management, 31, 111-118. 
40. Margaix, D. (2007): "Conceptos de web 2.0 y biblioteca 2.0: origen, definiciones y retos para las bibliotecas actuales" ["Web 2.0 concepts and library 2.0: origin, definitions, and challenges for current libraries”]. El profesional de la información, 16 (2), 95-106. [Spanish]

41. Montoya-Weiss, M.M, Voss, G.B. and Grewal, D. (2003): "Determinants of online channel use and overall satisfaction with a relational, multichannel service provider". Journal of the Academy of Marketing Science, 31, 448-458.

42. Morgan, R.M. and Hunt, S.D. (1994): "The Commitment - Trust Theory of Relationship Marketing”. Journal of Marketing, 58 (July), 20-38.

43. Nunnally, J.C. (1978): Psychometric Theory. 2nd ed. New York: McGraw-Hill.

44. Nunnally, J. and Bernstein, I.H. (1994): Psychometric Theory. New York: Mc Graw-Hill.

45. O'Reilly, T. (2005): What is Web 2.0: Design Patterns and Business Models for the Next Generation of Software [online]. O’Reilly Media. Available at: http://www.oreillynet.com/pub/a/oreilly/tim/news/2005/09/30/what-is-web-20.html [Accessed 28 May 2007].

46. Oliver, R.L. (1980): "A Cognitive Model of the Antecedents and Consequences of Satisfaction Decisions". Journal of Marketing Research, 17, 460-469.

47. Oliver, R.L. (1997): "Loyalty and Profit: Long Term Effect of Satisfaction". In: R. Oliver, ed. Satisfaction: A Behavioral Perspective on the Consumer. Companies, Inc, United States: McGraw Hill.

48. Oliver, R.L. and Bearden, W.O. (1983): "The role of involvement in satisfaction processes". Advances in Consumer Research, 10, 250-255.

49. Oliver, R.L. and Linda, G. (1981): "Effect of satisfaction and its antecedents on consumer preference and intention". Advances in Consumer Research, 8, 88-93.

50. Ortega, S. (2007): "Evolución del perfil del usuario: Usuarios 2.0" ["Evolution of user profile: Users 2.0”]. No Sólo Usabilidad Journal, 6. [Spanish]

51. Rheingold, H. (2002): Smart Mobs: The Next Social Revolution. Cambridge: Perseus Books Group.

52. Rheingold, H. (2005): Mobile Phones, Ritual Interaction and Social Capital [online]. The Feature. Available at: http://www.thefeaturearchives.com/topic/Culture/Mobile_Phones_Ritual_Interaction_and_Social_Capital. $\underline{\text { html }}$ [Accesed 15 February 2006].

53. Ribes, X. (2007): "La Web 2.0. El valor de los metadatos y de la inteligencia colectiva" ["Web 2.0. The metadata and collective intelligence value"]. Telos, Cuadernos de Comunicación e Innovación, 73 (October-December). [Spanish]

54. Riegner, C. (2007): "Word of Mouth on the Web: The Impact of Web 2.0 on Consumer Purchase Decisions". Journal of Advertising Research, (December), 436-447.

55. Rizzolatti, G. and Sinigaglia, C. (2006): La neurona espejo. Los mecanismos de la empatía emocional [The mirror neuron. The mechanisms of emotional empathy]. Barcelona: Ed. Paidós. [Spanish]

56. Rosen, C. (2005): “The age of egocasting. The New Atlantis". A Journal of Technology and Society, 51-72. Available at: http://www.thenewatlantis.com/archive/7/rosen.htm

57. Roy, M.C., Dewit, O. and Aubert, B.A. (2001): “The Impact of Interface Usability on Trust in Web Retailers”. Internet Research: Electronic Networking Applications and Policy, 11 (5), 388-398.

58. Siguaw, J., Simpson, P. and Baker, T. (1998): "Effects of Supplier Market Orientation on Distributor Market Orientation and the Channel Relationship: the Distributor Perspective". Journal of Marketing, 62 , (July), 99-111.

59. Smith, J. and Barclay, D.W. (1997): “The Effects of Organizational Differences and Trust on the Effectiveness of Selling Partner Relationships". Journal of Marketing, 61, 3-21.

60. Steenkamp, J.B. and Van Trijp, H.C.M. (1991): "The use of LISREL in Validating Marketing Constructs". International Journal of Research in Marketing, 8, 283-299.

61. Walczuch, R., Seelen, J. and Lundgren, H. (2001): "Psychological determinants for consumer trust in eretailing”. Eighth Research Symposium on Emerging Electronic Markets. Available at: http://wwwi5.informatik.rwth-aachen.de/conf/rseem2001/papers/walczuch.pdf

62. Yi, Y. (1990): “A critical review of consumer satisfaction”. In: V.A. Zeithaml, ed. Review of Marketing. Chicago: American Marketing Association, 68-123. 